\title{
PSMD11 wt Allele
}

National Cancer Institute

\section{Source}

National Cancer Institute. PSMD11 wt Allele. NCI Thesaurus. Code C125535.

Human PSMD11 wild-type allele is located in the vicinity of $17 q 11.2$ and is approximately $39 \mathrm{~kb}$ in length. This allele, which encodes $26 \mathrm{~S}$ proteasome non-ATPase regulatory subunit 11 protein, is involved in proteasome assembly and activity. 